\title{
PENGARUH MEDIA PEMBELAJARAN DAN MOTIVASI BELAJAR TERHADAP HASIL BELAJAR DESAIN SISTEM INSTRUKSIONAL PENDEKATAN TPACK
}

\author{
Harun Sitompul ${ }^{1}$, Denny Setiawan ${ }^{2}$, Erward Purba $^{3}$ \\ Teknologi Pendidikan, dan Pendidikan Dasar Pascasarjana Unimed, Sumatera Utara \\ prof_runsit@yahoo.co.id ${ }^{1}$,geodeny@ymail.com ${ }^{2}$, edw.purba@gmail.com ${ }^{3}$
}

\begin{abstract}
Abstrak: Penelitian ini bertujuan untuk: (1) mengetahui pengaruh penggunaan media terhadap hasil belajar desain sistem instruksional pendekatan TPACK, (2) mengetahui pengaruh motivasi belajar terhadap hasil belajar desain sistem instruksional pendekatan TPACK, dan (3) mengetahui interaksi antara penggunaan media pembelajaran dan motivasi belajar mahasiswa dalam mempengaruhi hasil belajar desain sistem instruksional pendekatan TPACK. Penelitian ini dilaksanakan pada mahasiswa yang mengambil matakuliah desain sistem instruksional dengan purposive sampling. Metode penelitian adalah kuasi eksperimen dengan desain faktorial $2 \times 2$. Uji statistik yang digunakan adalah statistik deskriptif untuk menyajikan data dan dilanjutkan dengan statistik inferensial dengan menggunakan ANAVA dua jalur dengan taraf signifikan $\alpha=0,05$ yang dilanjutkan dengan uji Scheffe. Hasil penelitian ini menunjukkan bahwa; (1) hasil belajar desain sistem instruksional pendekatan TPACK lebih tinggi dibandingkan dengan konvensional; (2) Hasil belajar hasil belajar desain sistem instruksional pendekatan TPACK pada motivasi belajar tinggi lebih tinggi daripada motivasi belajar rendah; dan terdapat interaksi antara media pembelajaran dengan motivasi belajar terhadap hasil belajar desain sistem instruksional pendekatan TPACK.
\end{abstract}

Kata Kunci: media pembelajaran, motivasi belajar, desain sistem instruksional, TPACK

Abstract: This study aims to: (1) determine the effect of media usage on instructional design instructional outcomes of TPACK approach, (2) to know the influence of learning motivation on instructional instructional design result of TPACK approach, and (3) to know the interaction between the use of instructional media and student learning motivation in influencing instructional instructional design result of TPACK approach. This research is conducted on students who take instructional course design course with purposive sampling. The research method is quasi experiment with $2 \times 2$ factorial design. Statistical test used is descriptive statistic to present the data and continued with inferential statistic by using two way ANOVA with significant level $\alpha=$ 0,05 followed by Scheffe test. The results of this study indicate that; (1) the instructional instructional design result of TPACK approach is higher than conventional; (2) The learning outcomes of instructional system design of TPACK approach on higher learning motivation is higher than low learning motivation; and there is interaction between learning media with learning motivation to instructional design instructional system result TPACK approach.

Keywords: learning media, learning motivation, instructional system design, TPACK

\section{PENDAHULUAN}

Usaha ini harus dilakukan dalam rangka meningkatkan hasil belajar. Salah satu caranya dengan menggunakan strategi pembelajaran yang bervariasi dan menarik dalam menyampaikan materi pelajaran. Menggabungkan suatu metode dengan metode lainya sehingga didapatkan suatu metode yang tepat sesuai dengan karakteristik mahasiswa dan strategi pembelajaran yang digunakan dosen hendaknya dapat diterima mahasiswa yang memiliki gaya belajar yang berbeda beda. Ciri - ciri perkembangan IPTEK yaitu; (1) daya muat untuk mengumpulkan, menyiapkan, manipulasikan, dan menyajikan informasi meningkat; (2) kecepatan penyajian informasi meningkat; (3) miniaturisasi perangkat keras; (4) keragaman pilihan informasi; (5) menurunnya biaya perolehan informasi; (6) mudahnya penggunaan produk teknologi informasi; (7) distribusi informasi yang semakin cepat dan luas; (8) pemecahan masalah yang lebih baik dan dibuatnya prediksi masa depan yang lebih tepat (Miarso, 2004:664-665).

Penggunaan Pembelajaran berbantukan komputer secara perorangan memungkinkan 
untuk mengawasi pemahaman mahasiswa secara tetap dan respons yang diberikan oleh PBK berdasarkan kebutuhan individu mahasiswa . Mahasiswa yang berposisi sebagai pengguna komputer atau disebut dengan EndUser Computing yang disingkat dengan (EUC) adalah pengguna konputer secara langsung oleh seseorang untuk menyelesaikan masalah yang memerlukan pemecahan masalah berbasis komputer (computer based solution) dengan cepat (Horrison dan Rainer, 2016).

Russell (2011:7) "Media merupakan bentuk jamak dari perantara (medium), yang menjadi sarana komunikasi. Hamid (2009:55), media pembelajaran adalah komponen strategi penyampaian yang dapat dimuati pesan yang akan disampaikan kepada pebelajar, apakah itu orang, alat atau bahan. Heinich, Molenda, dan Russel (Instructional Media, 1990) diungkapkan bahwa media "is a channel of comunication. Derived from the latin word for "between", the term refers "to anything that carries information between a source and receiver". Heinich (1989: 334) Computer systems can deliver instruction directly to students by allowing them to interact with lessons programmed into the system; this is referred to as Computer- Assisted Instruction (CAI). The various utilization possibilities can best bediscussed in terms of the various instructionsl modes that the computer can facilitate most effectively: drill and practice, tutorial, gaming, simulation, discovery, and problem solving. Smaldino (2005: 148) "The hearth of an interactive media system is the computer, which provides the intelegence and interavtivity required. The computer can command the system to present audio or vidio information, wait for learner's response, and branch to the appropriate ponit in the instructional-program from that response”.

Smaldino (2005: 148) mengemukakan, "interactive media is a powerfull, practical method for individualizing and personalizing instruction". Komputer berperan sebagai manajer dalam proses pembelajaran yang dikenal dengan nama Computer-Managed Instruction (CMI). Ada pula peran komputer sebagai peran tambahan dalam belajar; pemanfaatannya meliputi penyajian informasi isi materi pelajaran, latihan, atau kedua-duanya. Multimedia interaktif merupakan alat atau sarana ataupun mediaganda (multiple media), berupa teks, audio, grafik, animasi, suara teks, gambar, dan vidio, yang penayangannya bergerak dinamis berubah dengan perlahan yang memerlukan interaksi mahasiswa serta diikutsertakan lebih besar dalam aktivitas pembelajaran semuanya dapat disatukan dalam penyampian materi, metode yang dirancang secara sistematis dan menarik untuk mencapai kompetensi/subkompetensi mata pelajaran yang diharapkan dengan menggunakan komputer dan mahasiswa akan lebih mudah memahami konsep - konsep yang bersifat abstrak serta dengan bantuan seminimal mungkin dari guru atau orang lain, dan belajar sesuai dengan kecepatan belajar masing - masing (selfpacing).

Heinich (1985:315) menjelaskan pembelajaran tutorial adalah: "Programmed tutoring (also referred to as structured tutoring) is one-to one method of instruction in which the decisions to be made by the tutor are "programmed" in advance by means of carefully structured printed instructions." Hackbarth (1996) tutorial adalah pengenalan dan penjelasan mengenai konsep-konsep dan keterampilan-keterampilan yang akan diperaktekkan. Seperti bahan-bahan pembelajaran terprogram, dan menyakinkan kerangka informasi dan pertanyaan-pertanyaan. Rusman (2009) media interaktif model tutorial berbantuan komputer adalah sebagai tutor yang berorientasi pada upaya dalam membangun perilaku mahasiswa melalui penggunaan komputer. Adapun karakteristik media pembelajaran interaktif tutorial adalah sebagai: (1) informasi baru; (2) bersifat konsep; (3) luas dan mendalam; (4) memerlukan kontrol dan mastery learning; (5) berhubungan antara bagian pokok materi yang satu dan lainnya; (6) memungkinkan dipelajari secara berulang; (7) memiliki pola berpikir dan arah pembelajaran bercabang (branching); (8) membutuhkan kontrol waktu dalam setiap segmen materi atau mastery learning secara keseluruhan; dan (9) menekankan pada pengoptimalan pencapaian aspek kognitif.

Menurut Dimyati dan Mudjiono (2006:34) menyatakan bahwa motivasi dipandang sebagai dorongan mental yang menggerakkan, menyalurkan, dan mengarahkan sikap dan perilaku individu belajar. Jadi motivasi dalam belajar sangatlah penting sehingga tercapai tingkat pengetahuan akan mengoperasikan komputer yang baik. Motivasi mahasiswa harus mendapat perhatian sebelum memulai pelajaran agar guru dapat menentukan strategi pembelajaran yang diterapkan. 
Paul \& Dale (2002:5) "Motivation is the process whereby goal-directed activity is instigated and sustained" and "Motivation is a process rather than a product". Menurut Sardiman (2011:73) motivasi belajar dapat dikatakan sebagai keseluruhan daya penggerak dari dalam dan di dalam diri mahasiswa yang menimbulkan kegiatan belajar, yang menjamin kegiatan kelangsungan dari kegiatan belajar dan yang memberikan arah pada kegiatan belajar, sehingga tujuan yang akan dikehendaki oleh subjek belajar itu dapat dicapai. Amirullah dan Hanafi (2002) mengemukakan motivasi belajar dapat difenisikan sebagai kondisi yang berpengaruh membangkitkan, mengarahkan, dan memelihara perilaku yang berhubungan dengan lingkungan belajar.

Sardiman (2007:75) motivasi belajar dapat juga diartikan sebagai serangkaian usaha untuk menyediakan kondisi-kondisi tertentu, sehingga seseorang mau dan ingin melakukan sesuatu, dan bila ia tidak suka, maka akan berusaha untuk meniadakan atau mengelak perasaan tidak suka. Motivasi belajar adalah: serangkaian usaha untuk menyediakan kondisikondisi tertentu, dorongan (tenaga) atau faktor yang dapat membangkitkan, mempengaruhi, menimbulkan, mengarahkan, dan mengorganisasikan serta memelihara tingkah laku manusia yang berhubungan dengan lingkungan belajar dalam memenuhi cita-cita, aspirasi mahasiswa, semangat belajar yang akan membuat kepuasan mahasiswa dengan memberikan angka, hadiah, ulangan, hasil belajar serta pujian yang mempengaruhi mahasiswa dalam meningkatkan kemauan dan semangat belajar dalam mencapai tujuan pembelajaran.

\section{HASIL PENELITIAN}

Tabel 1. Rangkuman Hasil Perhitungan Analisis Deskriptif

\begin{tabular}{|c|c|c|c|c|}
\hline \multirow{2}{*}{\multicolumn{2}{|c|}{ Ringkasan Data }} & \multicolumn{2}{|c|}{ Penggunaan Multimedia Pembelajaran Interaktif } & \multirow[b]{2}{*}{ Total } \\
\hline & & Tutorial & Direct Instructional & \\
\hline \multirow[b]{2}{*}{$\begin{array}{c}\text { Motivasi } \\
\text { Belajar }\end{array}$} & Tinggi & $\begin{array}{c}N=12 \\
\sum X=530 \\
\sum X^{2}=15006 \\
\bar{X}=27,61\end{array}$ & $\begin{array}{c}N=15 \\
\sum X=474 \\
\sum X^{2}=12070 \\
\bar{X}=25\end{array}$ & $\begin{array}{c}\mathrm{N}=27 \\
\sum \mathrm{X}=1004 \\
\sum \mathrm{X}^{2}=27076 \\
\bar{X}=26,38\end{array}$ \\
\hline & Rendah & $\begin{array}{c}N=13 \\
\sum X=307 \\
\sum X^{2}=6919 \\
\bar{X}=21,78\end{array}$ & $\begin{array}{c}N=14 \\
\sum X=330 \\
\sum X^{2}=7960 \\
\bar{X}=23,57\end{array}$ & $\begin{array}{c}\mathrm{N}=27 \\
\sum \mathrm{X}=637 \\
\sum \mathrm{X}^{2}=14879 \\
\bar{X}=22,64\end{array}$ \\
\hline \multicolumn{2}{|c|}{100} & $\begin{array}{l}N=25 \\
\sum X=837\end{array}$ & $\begin{array}{l}N=29 \\
\sum X=804\end{array}$ & $\begin{array}{c}\mathrm{N}=54 \\
\sum \mathrm{X}=1641\end{array}$ \\
\hline
\end{tabular}

\section{METODE}

Pelaksanaan penelitian ini dilaksanakan pada mahasiswa pascasarjana teknologi pendidikan yang mengambil matakuliah DSI. Penentuan karakteristik mahasiswa kelas tersebut tidak dikelompokkan atas ranking dan pengelompokkan kelas unggulan tetapi dilakukan secara acak saja sewaktu penempatan Teknik pengambilan sampel dalam penelitian ini dengan purposive random sampling. Teknik ini dipilih karena yang di samping dari populasi adalah jumlah kelas bukan jumlah mahasiswa dalam populasi. Sampel yang diambil terdiri dari dua kelompok yaitu, satu kelompok kelas dilakukan pembelajaran menggunakan strategi pembelajaran Direct Instructional, dan satu kelas lainnya dilakukan strategi pembelajaran menggunakan multimedia interaktif Tutorial. Tenaga pengajar yang diterapkan untuk melakukan pembelajaran menggunakan multimedia pembelajaran interaktif Powerpoint diberikan pedoman treatment strategi pembelajaran mengenai cara penyajian materi pembelajaran.

Penelitian menggunakan metode eksperimen dangan rancangan quasi eksperimen. Teknik analisis data yang digunakan adalah Teknik Statistik Deskriptif dan inferensial. Teknik statistik inferensial digunakan untuk menguji hipotesis penelitian, dimana teknik statistik inferensial yang digunakan tenik analisis varians (ANAVA) dua jalur (desain faktorial $2 \times 2$ ) dan uji statistik yang digunakan adalah uji $F$ dengan $\alpha=0,005$. mahasiswa dalam kelompok masing- masing. 


\begin{tabular}{|c|c|c|}
\hline$\sum X^{2}=21925$ & $\sum X^{2}=20030$ & $\sum X^{2}=41955$ \\
$\bar{X}=25,06$ & $\bar{X}=24,72$ & $\bar{X}=24,75$ \\
\hline
\end{tabular}

Setelah data Tabel 1 diolah dengan Anava 2 jalur faktorial 2 × 2, maka diperoleh hasil analisis seperti ditunjukkan pada Tabel 2.

Tabel 2. Ringkasan Perhitungan Anava faktorial 2 x 2.

\begin{tabular}{|c|c|c|c|c|c|c|}
\hline Sumber Varians & $\mathrm{dk}$ & JK & RJK & $F_{\text {hitung }}$ & $\mathrm{F}_{\text {tabel }} 0,05$ & ket \\
\hline Penggunaan multimedia (A) & 1 & 42,20 & 42,20 & 3,91 & 3,16 & Signifikan \\
\hline Motivasi belajar (B) & 1 & 206,48 & 206,48 & 22,97 & 3,16 & Signifikan \\
\hline Interaksi (AB) & 1 & 153,63 & 153,63 & 11,51 & 3,16 & Signifikan \\
\hline Galat & 50 & 713,75 & 13,34 & & & \\
\hline Total & 53 & 1226,06 & & & & \\
\hline
\end{tabular}

Pada tabel ringkasan ANAVA untuk penggunaan multimedia pembelajaran interaktif dapat disimpulkan adanya interaksi antara penggunaan multimedia pembelajarn interaktif dengan motivasi belajar yang mempengaruhi hasil belajar DSI berorientasi TPACK. Hipotesis penelitian yang menyatakan hasil belajar DSI berorientasi TPACK mahasiswa yang menggunakan multimedia pembelajaran interaktif tutorial lebih tinggi dari pada mahasiswa yang dibelajarkan dengan menggunakan multimedia pembelajaran langsung teruji kebenaranya. Hipotesis penelitian yang menyatakan hasil belajar TIK mahasiswa yang memiliki motivasi belajar tinggi lebih tinggi dari pada mahasiswa yang memiliki motivasi belajar rendah teruji kebenarannya. Dan Hipotesis penelitian yang menyatakan terdapat interaksi antara MPI dan motivasi belajar dalam mempengaruhi hasil belajar DSI berorientasi TPACK teruji kebenarannya. Sehubungan dengan adanya interaksi maka perlu Selanjutnya dilakukan uji lanjut dengan uji Scheffe.

Multimedia pembelajaran interaktif latihan dan praktik merupakan pembelajaran dengan jalan melatih mahasiswa terhadap bahan pelajaran yang sudah diberikan. Metode dalam pembelajaran ini menanamkan kebiasaan tertentu dalam bentuk latihan. Dengan demikian latihan yang terus menerus diharapkan akan tertanam kebiasaan, kecepatan, ketepatan, kesempurnaan dalam melakukan sesuatu, serta dapat pula dipakai sebagai suatu cara mengulangi bahan latihan yang telah disajikan, juga dapat menambah keceapatan. (Rusman, 2009:283).

Dalam pembelajaran DSI berorientasi TPACK, pada multimedia pembelajaran interaktif turotial mahasiswa lebih banyak melakukan latihan terhadap bahan pelajaran yang sudah diberikan. Multimedia pembelajaran menanamkan kebiasaan tertentu dalam bentuk latihan. Dengan latihan yang terus menerus diharapkan akan tertanam kebiasaan, kecepatan, ketepatan, kesempurnaan dalam melakukan sesuatu, serta dapat pula dipakai sebagai suatu cara mengulangi bahan latihan yang telah disajikan, juga dapat menambah kecepatan. (Rusman, 2009:283). Pada multimedia pembelajaran interaktif latihan dan praktik ini latihan yang diberikan dosen yang dimaksud untuk melatih keterampilan mahasiswa dalam pembelajaran berbasis TIK terutama dalam pelaksanaan pembelajaran yang dilakukan

Dari penelitian ini diperoleh rata-rata hasil belajar DSI berorientasi TPACK mahasiswa yang dibelajarkan dengan menggunakan media pembelajaran interaktif turitoial lebih tinggi daripada hasil belajar DSI berorientasi TPACK mahasiswa yang dibelajarkan dengan multimedia pembelajaran langsung, meskipun hasil belajar rata-rata mahasiswa antara kedua kelompok tidak terlalu jauh berbeda. Dengan demikian hasil penelitian yang ditemukan sesuai dengan pendapat yang dikemukakan Sadiman (2003) bahwa multimedia pembelajaran mendukung kegiatan belajar, dimana fungsi atau kegunaan media anatara lain: (a) membuat konkrit konsep yang abstrak, (b) membawa obyek yang berbahaya atau sukar didapat ke dalam lingkungan belajar, (c) menampilkan objek yang terlalu besar, (d) menampilakn objek yang tidaka dapat diamati dengan mata telanjang, (e) mengamati gerakan yang terlalu cepat, (f) memungkinkan mahasiswa berinteraksi langsung dengan 
lingkungan, (g) memungkinkan kesegaran pengamatan dan persepsi bagi pengamatan belajar mahasiswa, (h) membangkitkan motivasi belajar, (i) menyajikan informasi belajar secara konsisten dan dapat diulangi maupun disimpan menurut kebutuhan, (j) menyajikan pesan atau informasi belajar secar serempak, membatasi batasan waktu maupun ruang, dan (k) mengontrol arah maupun kecepatan belajar mahasiswa. Pemilihan media yang tepat dalam pembelajaran akan membuat mahasiswa semakin memahami dan mendalami isi materi pembelajaran dan berperan aktif untuk mencari dan mengali materi sehingga dapat meningkatkan hasil belajar DSI berorientasi TPACK mahasiswa.

Beberapa hasil penelitian yang mendukung berhasilnya pembelajaran dengan multimedia berbasis komputer adalah sebagai berikut. Pertama, hasil penelitian Woolf \& Hall (2005) yang berjudul "Interactive multimedia systems for teaching and learning" menunjukkan bahwa pembelajaran multimedia berbasis komputer lebih efektif dan dapat memberikan pengalaman yang berkualitas dibandingkan pengajaran yang tradisional. Kedua, hasil penelitian Jenks \& Springer (2005) yang berjudul "A view of the research of efficacy of CAI" menunjukkan bahwa pemberian remedial dengan komputer lebih efektif dibandingkan dengan remedial yang tidak menggunakan komputer.

Mata pelajaran DSI berorientasi TPACK merupakan mata pelajaran yang mengharuskan mahasiswa memiliki sejumlah kompetensi khususnya dalam bidang instruksional. Kemampuan ini akan lebih mudah diperoleh mahasiswa yang memiliki motivasi belajar tinggi untuk mudah memahami dan berani mencoba untuk berkreasi dan menangkap isi materi yang dibelajarkan dengan menggunakan multimedia pembelajaran interaktif berbasis komputer. Mahasiswa yang memiliki motivasi belajar tinggi akan lebih cepat menangkap isimateri yang disajikan dengan cara belajar mandiri. Motivasi belajar akan lebih berkembang jika mahasiswa mampu secara aktif memotivasi diri secara baik dalam melaksanakan kegiatan pembelajaran sesuai dengan penyajian materi melalui multimedia pembelajaran interaktif berbasis komputer. Praktek langsung akan semakin meningkatkan hasil belajar DSI berorientasi TPACK mahasiswa yang memiliki motivasi belajar tinggi. Selain itu mahasiswa juga akan aktif sehingga akan merangsang mahasiswa untuk bergerak terus mengikuti langkah-langkah yang ada didalam sajian pembelajaran langsung.

Bagi mahasiswa yang memiliki motivasi belajar rendah, pembelajaran DSI berorientasi TPACK akan lebih baik dibelajarkan dengan menggunakan multimedia pembelajaran interaktif turorial dibanding dengan multimedia pembelajaran interaktif langsung. Hal ini disebabkan akan lebih mudah bagi mahasiswa yang memiliki motivasi belajar rendah untuk memahami materi dengan cara melakukan pengulangan dengan latihan-latihan yang berulang pada materi yang diberikan. Dalam multimedia pembelajaran interaktif dapat pula dipakai sebagai suatu cara mengulangi bahan latihan yang disajikan, juga dapat menambah kecepatan. Mahasiswa yang memiliki motivasi belajar rendah pada umumnya kurang mau untuk mencoba metode pembelajaran yang baru dan bisanya mereka akan lebih nyman dengan cara belajar yang konvensional.

Penggunaan multimedia pembelajaran berbasis komputer juga dapat membuat pembelajar lebih mengingat materi yang dipelajari. Hal ini sesuai dengan hasil riset dari Computer Technology Reaserch tahun 1993 bahwa "Seseorang hanya dapat mengingat apa yang dia lihat sebesar 20\%, dan apa yang dia dengar sebesar $30 \%$, apa yang dia dengar dan lihat sebesar 50\%, dan sebesar $80 \%$ dari apa yang dia lihat, dengar, dan kerjakan secara simultan. Pencapaian $80 \%$ tersebut sangat dimungkinkan dapat dicapai dengan menggunakan multimedia pembelajaran berbasis komputer yang interaktif (Priyanto, 2009: 4).

Meskipun multimedia pembelajaran interaktif langsung lebih baik digunakan bagi mahasiswa yang memiliki motivasi belajar tinggi, namun tidak tertutup kemungkinan dapat juga dipakai oleh mahasiswa yang memiliki motivasi belajar rendah. Hal ini dikarenakan melalui multimedia pembelajaran interaktif langsung mahasiswa dapat mengikuti langkah demi langkah materi pembelajaran secara langsung oleh mahasiswa dan secara langsung dapat dipraktekkkan oleh mahasiswa itu sendiri. Dan hasil penelitian ini juga dapat menunjukkan bahwa hasil belajar DSI berorientasi TPACK mahasiswa yang menggunakan multimedia pembelajaran interaktif tutorial dan multimedia pembelajaran interaktif langsung dengan mahasiswa yang 
memiliki motivasi belajar tinggi tidak terlalu jauh berbeda, artinya mahasiswa yang memiliki motivasi belajar tinggi dapat menggunakan kedua media tersebut.

Berdasarkan hasil penelitian dan pembahasan yang dikemukakan sebelumnya maka dapat disimpulkan bahwa:

1. Hasil belajar DSI berorientasi TPACK mahasiswa yang dibelajarkan dengan menggunakan multimedia interaktif tutorial lebih tinggi dibandingkan dengan hasil belajar DSI berorientasi TPACK mahasiswa yang dibelajarkan dengan menggunakan multimedia interaktif langsung.

2. Hasil belajar DSI berorientasi TPACK mahasiswa yang memiliki motivasi belajar tinggi lebih tinggi daripada hasil belajar DSI berorientasi TPACK mahasiswa yang memiliki motivasi belajar rendah

3. Terdapat interaksi antara multimedia interaktif berbasis komputer dalam pembelajaran dengan motivasi belajar terhadap hasil belajar

\section{DAFTAR PUSTAKA}

Arsyad. (2013). Media Pembelajaran. Jakarta: Raja Grafindo Persada

Dale, Pintrick. (2000). Motivation in Education Theory Research and Aplication, Second Edition, New Jersey

Dimyati dan Mudjiono, (2006). Belajar dan Pembelajaran. Jakarta: Rineka Cipta

Heinich, Molenda \& Russell. 1985. Instructional Media and The New Tecology of Instructional, Canada: John Wiley \& Sons, Inc

Hackbarth, S. (1996). The educational technology handbook. Englewood Cliffs, New Jersey: Educational Technology Publications Inc.

Heinich, Molenda, \& Russell. (1985). Instructional Media. New York: John Wiley \& Sons

\section{PENUTUP}

Jenks, M. S. \& Springer, J. M. (2005). A view of the research of efficacy of CAI. electronic journal for the integration of technology in education vol 1 no. 2 . Diambil pada tanggal 28 September 2005 dari http://ejite.isu.edu/ Volume1No2/Jenks.pdf

Miarso Yusufhadi. (2005). Menyemai Benih Teknologi Pendidikan. Jakarta: Balai Pustaka

Priyanto, D. (2009). Pengembangan multimedia pembelajaran berbasis komputer. Jurnal pemikiran alternatif pendidikan. Insani/Vol 14/No 1/JanApr 2009-110.

Rusman. (2009). Majemen Kurikulumn. Jakarta: Rajawali Press

Sadiman, A. S, Raharjo, Haryono A, Rahardito. (2003). Media Pendidikan, Pengertian, Pengembangan dan pemanfaatannya. Jakarta: Rajawali Pres

Sadiman. (2006). Teknologi Informasi dan Komunikasi untuk SMA Kelas XI. Jakarta: Erlangga

Sardiman. (2014). Interaksi dan Motivasi Belajar Mengajar. Jakarta: Raja Grafindo Persada

Sadiman, A. S, Raharjo, Haryono. (2007). Media Pendidikan. Jakarta: Raja Grafindo Persada

Smaldino, Russell, Heinich, \& Molenda. (2005). Instructional Tecnology and Media for Learning. New Jersey: Pearson Education, Inc

Woolf, B. \& Hall, W. (2005). Interactive multimedia systems for teaching and learning. Diambil tanggal 20 September 2005 dari http://ckc.cs. umass.edu/ckc/ publications/ multimedia_pedagogues.pdf 